\title{
Peperomia pellucida leaf extract as immunostimulator in controlling motile aeromonad septicemia due to Aeromonas hydrophila in red hybrid tilapia, Oreochromis spp. farming
}

\author{
S. W. Lee ${ }^{1}$, K. Y. Sim ${ }^{1}$, W. Wendy ${ }^{2}$ and A. K. Zulhisyam ${ }^{1}$
}

1. Faculty of Agro Based Industry, Universiti Malaysia Kelantan Jeli Campus, 17600, Jeli, Kelantan, Malaysia;

2. School of Fisheries and Aquaculture Sciences, Universiti Malaysia Terengganu, Kuala Terengganu, 21030, Terengganu, Malaysia.

Corresponding author: S. W. Lee, e-mail: leeseongwei@yahoo.com,

KYS: sk.yuen@umk.edu.my,wW: wendy@umt.edu.my, AKZ: zulhisyam.a@umk.edu.my

Received: 06-06-2015, Revised: 08-01-2016, Accepted: 23-01-2016, Published online: 05-03-2016

doi: 10.14202/vetworld.2016.231-234 How to cite this article: Lee SW, Sim KY, Wendy W, Zulhisyam AK (2016) Peperomia pellucida leaf extract as immunostimulator in controlling motile aeromonad septicemia due to Aeromonas hydrophila in red hybrid tilapia, Oreochromis spp. farming, Veterinary World, 9(3): 231-234.

\begin{abstract}
Aim: This study was revealed the potential of Peperomia pellucida leaf extract as an immunostimulator agent in controlling motile aeromonad septicemia due to Aeromonas hydrophila in red hybrid tilapia, Oreochromis sp.

Materials and Methods: In the present study, minimum inhibitory concentration (MIC) of $P$. pellucida leaf extract against $A$. hydrophila was determined through two-fold microbroth dilution method. The plant extract was screening for its active compound using a gas chromatograph mass spectrometer, and the effectiveness of $P$. pellucida leaf extract as an immunostimulator agent was evaluated. The experimental fish were fed with medicated feed at three different concentrations (25 mg/kg, PP-25; $50 \mathrm{mg} / \mathrm{kg}$, PP-50; and $100 \mathrm{mg} / \mathrm{kg}$, PP-100) of P. pellucida leaf extract for 1 week before they were intraperitoneally exposed to A. hydrophila. Enzyme-linked immunosorbent assay was carried out to determine the value of antibody response to $A$. hydrophila in fish from a group of fish that received medicated feed, and the percentage of total cumulative mortality of the experimental fish were observed at the end of the experiment.
\end{abstract}

Results: The results showed that the major bioactive compound is phytol (40\%), and the MIC value was $31.5 \mathrm{mg} / \mathrm{L}$. The value of antibody response to A. hydrophila in fish from a group of fish which received medicated feed (PP-25, $0.128 \pm 0.014$ optical density [OD]; PP-50, 0.132 $\pm 0.003 \mathrm{OD}$; and PP-100, 0.171 \pm 0.02 OD) was found significantly higher $(\mathrm{p}<0.05)$ compared to fish did not receive medicated feed $(0.00$ OD). Whereas, percentage cumulative mortality of fish from all groups of fish received medicated feed (PP-25, 18.0 $3.2 \%$; PP-50, 18.2 $\pm 2.8 \%$; and PP-100, $17.7 \pm 1.8 \%)$ were found significantly lower $(\mathrm{p}<0.05)$ compared to a group of fish did not receive medicated feed $(83.2 \pm 1.4 \%)$.

Conclusion: The findings of the present study indicated the huge potential of $P$. pellucida leaf extract as natural immunostimulator agent for aquaculture uses.

Keywords: Aeromonas hydrophila, immunostimulator, motile aeromonad septicemia, red hybrid tilapia.

\section{Introduction}

Recently, aquaculture activities are expanding rapidly to generate more aquaculture production in fulfilling demand from the market. The expansion of aquaculture industry is due to the declining of fishery production and overexploitation of fishery product from the open sea. Subsequently, aquaculture is gearing toward intensification with the expectation to produce more fish. However, bacterial disease is recognized as a major constraint to the development of aquaculture industry. One of the bacterial diseases known as motile aeromonad septicemia (MAS) due to

Copyright: Lee, et al. Open Access. This article is distributed under the terms of the Creative Commons Attribution 4.0 International License (http://creativecommons.org/licenses/by/4.0/), which permits unrestricted use, distribution, and reproduction in any medium, provided you give appropriate credit to the original author(s) and the source, provide a link to the Creative Commons license, and indicate if changes were made. The Creative Commons Public Domain Dedication waiver (http://creativecommons.org/ publicdomain/zero/1.0/) applies to the data made available in this article, unless otherwise stated.
Aeromonas hydrophila was reported to cause devastation to tilapia fish farms.

A. hydrophila was reported found in many aquatic animals. For instance, Lee et al. [1] claimed that A. hydrophila was found in diseased Malaysian giant prawn, Macrobrachium rosenbergii. Other study was also reported that this bacterium was responsible to the mass mortality of ornamental fish in the aquarium shop. Based on the literature survey, A. hydrophila was found in Mantis Shrimp, Squilla sp., African catfish, Clarias gariepinus, American bullfrog, Rana catesbeiana [2], Asian seabass, Lates calcarifer [3], golden pompano, Trachinotus blochii [4], silver catfish, Pangasius sutchi, and red hybrid tilapia, Oreochromis sp. [5].

Traditionally, commercial antibiotic was used in fish health management. However, cases of antibiotic resistance have been alarming the industry due to the misuse and over use of the commercial antibiotics in aquaculture. Therefore, this study was performed 
to reveal the potential of Peperomia pellucida leaf extract as an alternative antimicrobial agent for aquaculture uses.

\section{Materials and Methods \\ Ethical approval}

The study was conducted following approved guidelines of the Institutional Animal Ethics Committee.

\section{Bacterial isolate}

A. hydrophila isolated from diseased red hybrid tilapia, Oreochromis sp., at commercial farms in Kelantan, Malaysia was used in the experiment. The bacterial isolate was cultured using brain heart infusion broth (Oxoid, England) for $18 \mathrm{~h}$ at room temperature. The bacterial pellet was harvested by centrifugation at 13,500 rpm for $10 \mathrm{~min}$. The harvested bacterial pellet was washed twice using physiological saline, and the concentration of the bacterial isolate was adjusted to $10^{9}$ colony forming unit $/ \mathrm{mL}$ for challenged by intraperitoneal injection of $100 \mu \mathrm{l}$ of each inoculum, at a dose causing $50 \%$ mortality $\left(\mathrm{LD}_{50}\right)$.

\section{Plant extraction}

P. pellucida leaf extract was prepared immediately after bought from the local market. The plants were clean using tap water and subjected to oven dried for $24 \mathrm{~h}$ at $40^{\circ}$ C. P. pellucida leaf was extracted according to Lee et al. [6]. The extract was then stored at $-20^{\circ} \mathrm{C}$ for further use.

\section{Minimum inhibitory concentration (MIC) values determination}

MIC values were determined using two-fold micro broth dilution method in 96-wells microtiter plate format. The bacterial suspension was prepared as described above. Bacterial suspensions were inoculated into wells of a microtiter plate in the presence of the plant extract with concentration start from 0.15 to $31.5 \mathrm{mg} / \mathrm{L}$ and kanamycin as the positive control [7]. The growth of tested bacterial, A. hydrophila, was checked after $24 \mathrm{~h}(\mathrm{~s})$ incubation via enzyme-linked immunosorbent assay (ELISA) reader (Bio-Rad, USA) at $540 \mathrm{~nm}$. MIC value is determined as the lowest concentration of antimicrobial agent inhibits the visible growth of the inoculated bacteria [8].

\section{Determination of plant extracts chemical composition}

The chemical composition of the plant extract was carried out as described by Lee and Wendy [9]. The chromatographic procedure was performed using a gas chromatograph mass spectrometer QP2010GC-MS (Shimadzu, Japan) with autosampler. The sample was diluted 25 times with acetone and $1 \mu$ of sample was injected into a column. A fused silica capillary column HP5-MS $(30 \mathrm{~m} \times 0.32 \mathrm{~mm}$, film thickness $0.25 \mu \mathrm{m}$ ) was used. Helium was the carrier gas, and a split ratio of $1 / 100$ was used. The oven temperature used was maintained at $60^{\circ} \mathrm{C}$ for $8 \mathrm{~min}$. The temperature was then gradually raised at a rate of $3^{\circ} \mathrm{C}$ per min to $180^{\circ} \mathrm{C}$ and maintained at $180^{\circ} \mathrm{C}$ for $5 \mathrm{~min}$. The temperature at the injection port was $250^{\circ} \mathrm{C}$. The components of the test solution were identified by comparing the spectra with those of known compounds stored in the internal library.

\section{Medicated feed}

The fish pellets (Cargill, Malaysia) were purchased commercially before they were mixed with crude extract of $P$. pellucida leaf. Medicated feed was prepared in three different concentrations of $P$. pellucida leaf extract at $25 \mathrm{mg} / \mathrm{kg}$, PP-25; $50 \mathrm{mg} / \mathrm{kg}$, PP-50; and $100 \mathrm{mg} / \mathrm{kg}, \mathrm{PP}-100$. In the preliminary toxicity test, crude extract of $P$. pellucida showed adverse effect on the fish when given at concentrations of $150 \mathrm{mg} / \mathrm{kg}$ and above. The extract was coated onto fish pellet at a desired concentration and oven dried at $30^{\circ} \mathrm{C}$ for $24 \mathrm{~h}$. The prepared fish pellet was then kept at $-20^{\circ} \mathrm{C}$ for further use.

\section{Efficacy of medicated feed experiment}

The antimicrobial agent efficacy test was carried out to determine the effectiveness of P. pellucida leaf extract in preventing and controlling MAS in red hybrid tilapia due to A. hydrophila. A total of 15 groups of fish, where each group contains 10-15 fish were maintained in $20 \mathrm{~L}$ aquaria. Six groups of fish were used as control, where each three groups served as negative and positive control, respectively. Nine groups of fish were used in the treatment using three different concentration of $P$. pellucida leaf extract $(25 \mathrm{mg} / \mathrm{kg}$, PP-25; $50 \mathrm{mg} / \mathrm{kg}$, PP-50; and $100 \mathrm{mg} / \mathrm{kg}, \mathrm{PP}-100$ ), with triplicates for each treatment. The experimental fish were given medicated fish pellet at $2 \%$ body weight of fish a day for 1 week before the fish were exposed to A. hydrophila by intraperitoneal injection. The mortality of the infected fish was observed and recorded for 4 weeks. Simultaneously, the medicated and unmedicated fish pellet was continuously given to the fish for 4 weeks. Fish from each treatment was randomly sampled for weekly ELISA. The calculation of the fish mortality as shown below:

Total cumulative died fish $\times 100 \%$

Total experimental fish in aquaria

\section{Indirect ELISA}

ELISA was carried out as described by Shelby et al. [10] with some modification. Briefly, fish were bled from the caudal vein and the blood was collected into a micro-centrifuge tube. The blood was then allowed to clot for $1 \mathrm{~h}$ at $25^{\circ} \mathrm{C}$. The fish serum was harvested through centrifugation at $300 \mathrm{~g}$ and stored at $-80^{\circ} \mathrm{C}$ for further use. The MAS antigen was prepared by a whole cell dilution of $A$. hydrophila with carbonate buffer to $500 \mu \mathrm{g} / \mathrm{mL}$. A $100 \mu \mathrm{L}$ of MAS antigen was added to each well of the microtiter plate for $1 \mathrm{~h}$ at $25^{\circ} \mathrm{C}$. The wells were then blocked with $3 \%$ bovine serum albumin (Sigma, USA) for $1 \mathrm{~h}$ at $25^{\circ} \mathrm{C}$. After the incubation period, the wells were washed 5 times with phosphate-buffered saline (PBS) plus teewn-20 
(PBS-T). A volume of $100 \mu \mathrm{L}$ of a serum sample ( $1 \mu \mathrm{L}$ of serum diluted in $999 \mu \mathrm{L}$ of PBS-T) were added to three replicate wells of the plate followed by $30 \mathrm{~min}$ incubation at $25^{\circ} \mathrm{C}$. The wells were then washed 3 times with PBS-T. After washing, $100 \mu \mathrm{L}$ of goat anti-tilapia immunoglobulin serum (diluted 1: 5000 in PBS-T) was added to the wells followed by $30 \mathrm{~min}$ incubation at $25^{\circ} \mathrm{C}$. Again, after 3 times washing with PBS-T, $100 \mu \mathrm{L}$ of rabbit anti-goat peroxidase conjugate (diluted 1: 5000 PBS-T) was added into the wells. Finally, the wells were washed again with PBS-T followed by the addition of $100 \mu \mathrm{L}$ of $o$-phenylenediamine in urea-peroxide buffer into each well. The ELISA reaction was stopped at $15 \mathrm{~min}$ by adding $50 \mu \mathrm{l}$ of $3 \mathrm{M} \mathrm{H}_{2} \mathrm{SO}_{4}$. The optical densities (OD) of the reactions were read with the microplate reader (Bio-Rad, USA) at $490 \mathrm{~nm}$. Negative controls consisted of wells coated with antigen and no sample serum and wells with no antigen and a serum sample. The control reactions gave an optical density reading at 0.04 or less.

\section{Statistical analysis}

Statistical differences between mortality and ELISA values were analyzed with one-way analysis of variance using Tukey post-hoc multiple comparison tests at $5 \%$ of a significant level.

\section{Results and Discussion}

The results showed that the major bioactive compound is phytol $(40 \%)$, and the MIC value was $31.5 \mathrm{mg} / \mathrm{L}$. The value of antibody response to $A$. hydrophila in fish from a group of fish which received medicated feed (PP-25, 0.128 \pm 0.014 OD; PP-50, $0.132 \pm 0.003 \mathrm{OD}$; and PP-100, $0.171 \pm 0.02$ OD) was found significantly higher $(\mathrm{p}<0.05)$ compared to fish did not receive medicated feed (0.00 OD). Whereas, percentage of cumulative mortality in fish from all groups of fish received medicated feed (PP-25, 18.0 $\pm 3.2 \%$; PP-50, 18.2 $\pm 2.8 \%$; and PP-100, $17.7 \pm 1.8 \%)$ was found significantly lower $(\mathrm{p}<0.05)$ compared to a group of fish did not receive medicated feed $(83.2 \pm 1.4 \%)$ (Table- 1$)$.

In the present study, the major compound of P. pellucida leaf extract was phytol (39.12\%) followed by 2-naphthalenol, decahydro- (27.10\%), hexadecanoic acid, methyl ester (16.12\%) and 9,12-octadecadienoic acid (Z,Z)-, methyl ester (17.66) (Table-2). However, none of the identified compounds in the present study were reported by Bayma et al. and $\mathrm{Xu}$ et al. $[11,12]$, which may due to a different approach in characterizing chemical compounds in the plant extract. Previous studies have revealed the antimicrobial activity of $P$. pellucida leaf extract against various types of bacteria. For instance, Lee et al. [7] showed that the major compound of P. pellucida leaf extract is phytol which claimed to be responsible to the antimicrobial and antioxidant activity of the plant. This statement is supported by the study of Kumar et al. [13], where the study claimed that phytol is an important
Table-1: Cumulative mortality (\%) of fish of the present study.

\begin{tabular}{lc}
\hline Treatment & Cumulative mortality (\%) \\
\hline Control & $83.2 \pm 1.4$ \\
PP-25 & $18.0 \pm 3.2$ \\
PP-50 & $18.2 \pm 2.8$ \\
PP-100 & $17.7 \pm 1.8$ \\
\hline
\end{tabular}

Table-2: Compound composition of $P$. pellucida leaf extract.

\begin{tabular}{lc}
\hline Compound & Composition (\%) \\
\hline Phytol & 39.12 \\
2-Naphthalenol, decahydro- & 27.10 \\
Hexadecanoic acid, methyl ester & 16.12 \\
9,12-Octadecadienoic acid (Z, Z)-, & 17.66 \\
methyl ester & 100 \\
Total & \\
\hline
\end{tabular}

P. pellucida $=$ Peperomia pellucida

diterpene and possessed both antimicrobial and anticancer activities. In the literature, many studies were exploring the benefits of $P$. pellucida leaf extract. Nwokocha et al. [14] reported that P. pellucida was used as an anti-hypertensive remedy. However, none of the study revealed the potential of $P$. pellucida leaf extract as immunostimulator agent for aquaculture uses. Hence, this is the first report on the potential of P. pellucida leaf extract as an alternative of commercial antibiotic in fish health management.

Many studies have reported antimicrobial activity of plant against pathogenic bacteria from aquaculture sites. For example, Allium sativum extract [8], Cymbopogon nardus essential oil [9], Andrographis paniculata leaf extract [15], Michelia champaca seed and flower extracts [16], Syzygium aromaticum flower bud [17], Citrus microcarpa [18], Murdannia bracteata leaf extract [6], and many more. However, the mentioned studies were focus only on the in vitro antimicrobial activity of the plants. On the other hand, this study highlighted the mechanism and mode of action of the $P$. pellucida leaf extract in stimulating the immune system of the fish against infection of MAS due to $A$. hydrophila. In the near future, more immunological assays should be carried out to support the findings of the present study. For instance, immunological assays such as phagocytosis assay and chemiluminescence assay where these assays may give information on humoral and specific immune systems of fish and the response of the fish to pathogens [19].

\section{Conclusion}

Based on the finding of the present study showed the huge potential of P. pellucida leaf extract as immunostimulator in controlling motile septicemia motile (MAS) due to A. hydrophila infected in red hybrid tilapia, Oreochromis sp. Hence, we proposed that this plant extract can be incorporated in the fish feed to manage fish health. However, further study should be carried out in the near future before we can come to a conclusion. 


\section{Authors' Contributions}

SWL and KYS designed and supervised the study. SWL, WW, and AKZ conducted a study and analyzed the data. All authors contributed in the draft, revision, and approval of the final manuscript.

\section{Acknowledgments}

This project was funded by Minister of Education Malaysia under Niche Research Grant Scheme (vot no: R/NRGS/A0.700/00387A/006/2014/00152.

\section{Competing Interests} interests.

The authors declare that they have no competing

\section{References}

1. Lee, S.W., Najiah, M., Wendy, W., Zarol, A. and Nadirah, M. (2009) Multiple antibiotic resistance and heavy metal resistance profile of bacteria isolated from giant freshwater prawn (Macrobrachium rosenbergii) hatchery. Agric. Sci. China, 8(6): 740-745.

2. Lee, S.W., Najiah, M., Wendy, W., Nadirah, M. and Faizah, S.H. (2009) Occurrence of heavy metals and antibiotic resistance in bacteria from organs of American bullfrog (Rana catesbeiana) cultured in Malaysia. J. Ven. Anim. Toxins. Incl. Trop. Dis., 15(2): 353-358.

3. Lee, S.W., Najiah, M. and Wendy, W. (2010) Bacterial flora from a healthy freshwater Asian sea bass (Lates calcarifer) fingerling hatchery with emphasis on their antimicrobial and heavy metal resistance pattern. Vet. Arch., 80(3): 411-420.

4. Lee, S.W., Najiah, M. and Wendy, W. (2010) Bacteria associated with golden pompano (Trachinotus blochii) broodstock from commercial hatchery in Malaysia with emphasis on their antibiotic and heavy metal resistances. Front. Agric. China, 4(2): 332-336.

5. Lee, S.W., Najiah, M., Wendy, W. and Nadirah, M. (2010) Antibiogram and heavy metal resistance of pathogenic bacteria isolated from moribund cage cultured silver catfish (Pangasius sutchi) and red hybrid tilapia (Tilapia sp.). Front. Agric. China, 4(1): 116-120.

6. Lee, S.W., Wendy, W., Julius, Y.F.S., Desy, F.S. and Ahmad, A.I. (2010) Characterization of antioxidant, antimicrobial, anticancer property and chemical composition of Murdannia bracteata leaf extract. Pharmacol. Online, 3: 930-936.

7. Lee, S.W., Wendy, W., Julius, Y.F.S. and Desy, F.S. (2011)
Characterization of anticancer, antimicrobial, antioxidant property and chemical composition of Peperomia pellucida leaf extract. Acta Med. Iran., 49(10): 670-674.

8. Lee, S.W. and Najiah, M. (2008) Inhibition of Edwardsiella tarda and other fish pathogens by Allium sativum L. (Alliaceae) extract. Am. Eurasian J. Agric. Environ. Sci., 3(5): 692-696.

9. Lee, S.W. and Wendy, W. (2013) Chemical composition and antimicrobial activity of Cymbopogon nardus citronella essential oil against systemic bacteria of aquatic animals. Iran. J. Microbiol., 5(2): 147-152.

10. Shelby, R.A., Klesius, P.H., Shoemaker, C.A. and Evans, J.J. (2002) Passive immunization of tilapia, Oreochromis niloticus (L.), with anti Streptococcus iniae whole sera. J. Fish Dis., 25: 1-6.

11. Bayma, J.D., Arruda, M.S., Muller, A.H., Arruda, A.C. and Canto, W.C. (2000) A dimeric ArC compound from Peperomia pellucida. Phytochemistry, 55: 779-782.

12. Xu, S., Li, N., Ning, M.M., Zhou, C.H., Yang, Q.R. and Wang, M.W. (2006) Bioactive compounds from Peperomia pellucida. J. Nat. Prod., 69(2): 247-250.

13. Kumar, P.P., Kumaravel, S. and Lalitha, C. (2010) Screening of antioxidant activity, total phenolics and GC-MS study of Vitex negundo. Afr. J. Biochem. Res., 4(7): 191-195.

14. Nwokocha, C.R., Owu, D.U., Kinlocke, K., Murray, J. and Delgoda, R. (2012) Possible Mechanism of action of the hypotensive effect of Peperomia pellucida and Interactions between human cytochrome P450 enzymes. Med. Aromat. Plants, 1: 105.

15. Lee, S.W., Wendy, W., Julius, Y.F.S. and Desy, F.S. (2011) Characterization of antimicrobial, antioxidant, anticancer properties and chemical composition of Malaysian Andrographis paniculata leaf extract. Pharmacol. Online, 2: 996-1002.

16. Lee, S.W., Wendy, W., Julius, Y.F.S. and Desy, F.S. (2011) Characterization of antimicrobial, antioxidant, anticancer property and chemical composition of Michelia champaca seed and flower extracts. S. J. Pharm. Sci., 4(1): 19-24.

17. Lee, S.W., Najiah, M., Wendy, W. and Nadirah, M. (2009) Chemical composite on and antimicrobial activity of the essential oil of Syzygium aromaticum flower bud (Clove) against fish systemic bacteria isolated from aquaculture sites. Front. Agric. China, 3(3): 332-336.

18. Lee, S.W. and Najiah, M. (2009) Antimicrobial property of 2-hydroxypropane-1,2,3-tricarboxylic acid isolated from Citrus microcarpa extract. Agric. Sci. China, 8(6): 740-745.

19. Stewart, A., Vaughn, O., Scott, L., Steve, H., Carolyn, F. and James, W. (2008) Measurement of the Innate Cellular Immune Response of Hybrid Striped Bass and Rainbow Trout. Bulletin for the Western Regional Aquaculture Center (WRAC) Publication, Washington, DC. 